\title{
Influence of newly synthesized imidazolium ionic liquids on activated sludge process
}

\author{
Dorota Gendaszewska', Ewa Liwarska-Bizukojć1, Cedric Maton², Christian V. Stevens² \\ ${ }^{1}$ Lodz University of Technology, Poland \\ Institute of Fermentation Technology and Microbiology \\ ${ }^{2}$ Ghent University, Belgium \\ Faculty of Bioscience Engineering \\ Department of Sustainable Chemistry and Technology \\ *Corresponding author's e-mail: dorota.gendaszewska@gmail.com
}

Keywords: imidazolium ionic liquids, activated sludge, morphological parameters, removal, adsorption.

\begin{abstract}
This study investigates the influence of four imidazolium ionic liquids (ILs) present in wastewater on the activated sludge process. In addition, experiments with inactivated sludge to assess the capacity of this sorbent to remove ILs from the wastewater were conducted. It occurred that the presence of ionic liquids in wastewater reduces biomass growth and size of the sludge flocs. The strongest effect has been found for IL 6 (1-hexyl-2H3-methyl-4,5-dimethylimidazolium iodide) with the longest alkyl chain length. Also, the degree of ILs removal increases with the alkyl chain length and decreases with the increase of initial concentration of ILs in wastewater. IL 6 reaches the highest degree of ILs removal from wastewater but inhibits the biomass growth and growth of sludge flocs in a greater extent than other tested compounds. Moreover, it was confirmed that newly synthesized ionic liquids can be adsorbed onto inactivated sludge. IL 6 could be adsorbed in a higher degree than other ionic liquids. This adsorption was described by Langmuir isotherm, whereas adsorption of other ionic liquids was described by Freundlich isotherm.
\end{abstract}

\section{Introduction}

In recent years there has been an observed increase in interest of "green chemistry" in which ionic liquids (ILs) play an important role. However, there are some doubts whether ionic liquids are environmentally friendly. To fully understand the impact of these compounds on the environment, knowledge about the behavior of ionic liquids during biological wastewater treatment as well as mechanisms of ILs removal from the wastewater is needed. To describe the behavior of these xenobiotics in wastewater, the determination of ILs impact on the biomass concentration is necessary. Investigation of changes in morphology of activated sludge flocs exposed to these chemicals in wastewater also can be very useful. It is known that the initial concentration in wastewater and chemical structure of 1-alkyl-3-methylimidazolium liquids were determining factors affecting sludge biomass (Gendaszewska \& Liwarska-Bizukojć 2013). Nevertheless the impact of peralkylated structure on activated sludge process has not been carefully investigated yet. It is assumed that a chemical structure and initial concentration of these ionic liquids are also strongly correlated with their activity. Luis et al. (2007) have partially confirmed this assumption by the Microtox bioassay with bioluminescent bacteria Vibrio fischeri (Luis et al. 2007). Their research allows for predicting toxicity (EC 50) of ionic liquids depending on different combinations of ionic liquids groups. It was calculated that the addition of each carbon atom to $\mathrm{R}$ and $\mathrm{R} 1$ chains causes an increase in toxicity by about $11 \%$. What is more interesting, an additional methyl group in the ionic liquids molecule increases the toxicity by about $7 \%$ (Luis et al. 2007).

The next important issue that should be discussed is the mechanism of ILs removal from the wastewater. The basic process of pollutants decomposition is biodegradation. The loss of these substances in wastewater can also be caused by sorption on activated sludge. It is known that soil with more organic carbon sorbs ionic liquids better in comparison with soil with a lower carbon content (Studzińska et al. 2008). Other parameter determining the strength of adsorption is a molecular weight of the adsorbate. Substances with high molecular weight such as dyes are adsorbed much stronger than the substances of lower molecular weight (Paderewski 1999). Adsorption is generally described through isotherms. There are many types of isotherms shape for organic solutes which depend on the experimental data. Giles et al. (1974) have divided groups of isotherms into four classes and five subclasses. Each class corresponds with a different adsorption mechanism associated with the orientation of the molecules in the system (Giles et al. 1974).

The ability of ionic liquids to adsorb on sludge is rarely reported in the literature. Several reports focused on adsorption of ILs onto aquatic or mineral surfaces (Beaulieu et 
al. 2008, Studzińska et al. 2008, Mrozik et al. 2012). Gorman-Lewis \& Fein (2004) tested adsorption of dissolved 1-butyl-3methylimidazolium chloride $[\mathrm{Bmim}][\mathrm{Cl}]$ onto Gram-positive soil bacterial species Bacillus subtilis, onto gibbsite, quartz, and clay minerals (Gorman-Lewis \& Fein 2004). The greatest extent of adsorption was found for the clay. However, there is no adsorption of the $[\mathrm{Bmim}][\mathrm{Cl}]$ onto bacteria surfaces. The lack of adsorption is explained by the fact that the electrostatic and hydrophobic attractive forces are not sufficient to absorb the tested ionic liquid under given conditions (Gorman-Lewis \& Fein 2004). The activated sludge is a more complex adsorbent, therefore the study of adsorption on this material may give different results, what was confirmed by Markiewicz et al. (2009). They described an adsorption process of 1-methyl-3-octylimidazolium chloride [Omim $][\mathrm{Cl}]$ onto activated sludge and have found a high level of sorption of tested IL. This result shows that sorption plays a significant role in the removal of xenobiotics from wastewater (Markiewicz et al. 2009).

The main aim of this study was to determine the influence of four newly synthesized imidazolium ionic liquids on activated sludge process, including effect on flocs morphology. In addition, the adsorption capacity of inactivated sludge to remove ionic liquids from wastewater was evaluated.

\section{Materials and methods}

\section{Ionic liquids}

The ionic liquids investigated, 1-ethyl-2-isopropyl-3-methyl-4,5-dimethylimidazolium iodide, 1-ethyl-2-methyl-3-methyl4,5-dimethylimidazolium iodide, 1-ethyl-2H-3-methyl-4,5dimethylimidazolium iodide and 1-hexyl-2H-3-methyl4,5-dimethylimidazolium iodide were synthesized by the
Department of Sustainable Chemistry and Technology (Ghent University, Belgium). They are presented in Table 1. Ionic liquids tested differ in the amount of substituents and what is more important differ in the length of the alkyl chain. Every test in the shake flask was conducted separately for each of the four imidazolium ionic liquids studied.

\section{Culture of activated sludge in the shake flasks}

Aerobic activated sludge was taken from Combined Wastewater Treatment in Łódź (Poland). This sludge was used in all experiments. A sample of the sludge was washed twice using synthetic wastewater which was prepared in agreement with Polish Norm PN-72/C-04550. $40 \mathrm{ml}$ of activated sludge and $160 \mathrm{ml}$ of fresh synthetic wastewater with/without imidazolium ionic liquid were poured to $300 \mathrm{ml}$ Erlenmeyer flasks. The following concentrations of ionic liquids were applied: 1, 5, 25 and $50 \mathrm{mg} \mathrm{l}^{-1}$. The initial Chemical Oxygen Demand (COD) of wastewater (with/without imidazolium) used in the experiments in the shake flasks is presented in Table 2. Initial activated sludge biomass concentration (volatile suspended solids) was $0.635 \mathrm{~g} \mathrm{VSS}^{-1}$. The samples with and without ionic liquids (control runs) were shaken at $20 \pm 0.5^{\circ} \mathrm{C}$ in a thermostated rotary shaker Certomat ${ }^{\circledR}$ IS at $130 \mathrm{rpm}$ for 24 hours. Before shaking and after 24 hours of the test the following analyses for each sample were performed: ILs concentration, Chemical Oxygen Demand, gravimetric analysis and analysis of morphological parameters of the flocs.

\section{Adsorption experiments}

The inoculum was taken from the same source as in the previous test, however, it was prepared in another way. In the beginning the sludge was washed twice with tap water

Table 1. Chemical names and structure of the studied ionic liquids

\begin{tabular}{|l|l|l|}
\hline \multicolumn{1}{|c|}{ Name } & Code & Composition \\
\hline $\begin{array}{l}\text { 1-ethyl-2-isopropyl-3-methyl-4,5- } \\
\text { dimethylimidazolium } \\
\text { iodide }\end{array}$ & $\mathrm{IL} \mathrm{1}$ & \\
\hline $\begin{array}{l}\text { 1-ethyl-2-methyl-3-methyl-4,5- } \\
\text { dimethylimidazolium } \\
\text { iodide }\end{array}$ & $\mathrm{IL} \mathrm{2}$ \\
\hline $\begin{array}{l}\text { 1-ethyl-2H-3-methyl-4,5- } \\
\text { dimethylimidazolium } \\
\text { iodide }\end{array}$ & $\mathrm{IL} \mathrm{4}$ \\
\hline $\begin{array}{l}\text { 1-hexyl-2H-3-methyl-4,5- } \\
\text { dimethylimidazolium } \\
\text { iodide }\end{array}$ & $\mathrm{IL} 6$ & $\mathrm{C}_{9} \mathrm{H}_{17} \mathrm{~N}_{2} \mathrm{I}$ \\
\hline
\end{tabular}


Table 2. The average COD of the wastewater (with and without ionic liquids)

\begin{tabular}{|c|c|c|}
\hline Code & $\begin{array}{l}\text { Concentration } \\
\text { of ILs }\left(\mathrm{mgl}^{-1}\right)\end{array}$ & $\operatorname{COD}\left(\mathrm{mg} \mathrm{O}_{2} \mathrm{l}^{-1}\right)$ \\
\hline \multirow{4}{*}{ IL 1} & 1 & $386 \pm 16$ \\
\hline & 5 & $405 \pm 10$ \\
\hline & 25 & $431 \pm 7$ \\
\hline & 50 & $461 \pm 13$ \\
\hline \multirow{4}{*}{ IL 2} & 1 & $386 \pm 8$ \\
\hline & 5 & $419 \pm 19$ \\
\hline & 25 & $425 \pm 14$ \\
\hline & 50 & $478 \pm 4$ \\
\hline \multirow{4}{*}{ IL 4} & 1 & $385 \pm 8$ \\
\hline & 5 & $400 \pm 17$ \\
\hline & 25 & $422 \pm 15$ \\
\hline & 50 & $450 \pm 28$ \\
\hline \multirow{4}{*}{ IL 6} & 1 & $390 \pm 14$ \\
\hline & 5 & $410 \pm 4$ \\
\hline & 25 & $429 \pm 16$ \\
\hline & 50 & $482 \pm 5$ \\
\hline Control & 0 & $379 \pm 4$ \\
\hline
\end{tabular}

to reduce the amount of organic material. Subsequently, the sludge was inactivated by addition of $20 \mathrm{ml} \mathrm{l}^{-1}$ glutaric aldehyde. It has been reported that this toxic compound has no significant effect on sludge properties such as morphological parameters (Liwarska-Bizukojć 2008). This inactivation was controlled by microscopic observation. Also, the activity of sludge was determined using $2 \%$ solution of INT (Iodonitrotetrazolium chloride). Inactivated sludge was used in adsorption experiments for evaluation of sorption capacity of this sorbent. Erlenmeyer flasks $(300 \mathrm{ml})$ were filled with $60 \mathrm{ml}$ of inactivated sludge and $140 \mathrm{ml}$ of tap water with imidazolium ionic liquid was added. Concentrations of ionic liquids ranged from 1 to $100 \mathrm{mg} \mathrm{l}^{-1}$. All tests were performed with TSS (total suspended solids) concentrations of $1.07 \mathrm{~g} \mathrm{TSS}^{-1}$ and VSS (volatile suspended solids) concentration of $0.767 \mathrm{~g} \mathrm{VSS} \mathrm{1}^{-1}$. Control runs containing inactivated sludge and tap water were conducted in parallel. The samples were shaken at the same condition as in the previous test. Before and after the test in the shake flask, measurements of ILs concentration (in a filtrate) and gravimetric analysis were made.

\section{Sorption isotherm}

The description of the adsorption characteristics was done by means of determination of characteristic parameter and by the adjustment of isotherms. The ratio of the amount of ionic liquid sorbed by the inactivated sludge to the amount of the analyte in the solution at equilibrium state was calculated as sorption coefficient, $\mathrm{K}_{\mathrm{D}}$ :

$$
\mathrm{K}_{\mathrm{D}}=\frac{\mathrm{C}_{\mathrm{s}}}{\mathrm{C}_{\mathrm{w}}} \cdot 1000\left[\frac{\mathrm{L}}{\mathrm{kg}}\right]
$$

where $\mathrm{C}_{\mathrm{w}}$ is the equilibrium concentration in the liquid phase, $\left(\mathrm{mg} \mathrm{l}^{-1}\right)$ and $\mathrm{C}_{\mathrm{s}}$ is the amount of compounds adsorbed onto the sludge at equilibrium (mg $\mathrm{g} \mathrm{TSS}^{-1}$ ). Also, to describe the relationship between the amount of ionic liquids adsorbed and their concentrations at equilibrium in solution, two mathematical expressions, the Langmuir and Freundlich models, were used. Langmuir isotherm is represented by the equation:

$$
\mathrm{C}_{\mathrm{S}}=\frac{\mathrm{K}_{\mathrm{L}} \cdot \mathrm{q}_{\mathrm{L}} \cdot \mathrm{C}_{\mathrm{W}}}{1+\mathrm{K}_{\mathrm{L}} \cdot \mathrm{C}_{\mathrm{w}}}
$$

The Langmuir equation can be rewritten in the following form:

$$
\frac{1}{C_{S}}=\frac{1}{C_{w} \cdot q_{L} \cdot K_{L}}+\frac{1}{q_{L}}
$$

where $\mathrm{K}_{\mathrm{L}}$ and $\mathrm{q}_{\mathrm{L}}$ are the Langmuir adsorption constant. Freundlich isotherm is represented by the equation:

$$
\mathrm{C}_{\mathrm{s}}=\mathrm{K}_{\mathrm{f}} \cdot \mathrm{C}_{\mathrm{w}}^{\frac{1}{\mathrm{n}}}
$$

The Freundlich isotherm can be linearized to the logarithmic form:

$$
\log \mathrm{C}_{\mathrm{s}}=\log \mathrm{K}_{\mathrm{f}}+\frac{1}{\mathrm{n}} \log \mathrm{C}_{\mathrm{w}}
$$

where $\mathrm{K}_{\mathrm{f}}$ and $\mathrm{n}$ are the Freundlich adsorption constants. The experimental data were fitted to the Freundlich or Langmuir isotherm equation and the values of adsorption parameters $\left(\mathrm{K}_{\mathrm{f}}, \mathrm{n}\right.$ or $\left.\mathrm{K}_{\mathrm{L}}, \mathrm{q}_{\mathrm{L}}\right)$ were estimated using non-linear regression (OriginPro 9.0.0. 32-bit SR-2). 


\section{Analytical methods}

Concentrations of ionic liquids were determined using UPLC (Waters, USA). Description of the chromatographic system and the measurement conditions have been presented elsewhere (Gendaszewska \& Liwarska-Bizukojć 2013). Chemical Oxygen Demand (COD) and gravimetric analysis were determined in agreement with the standard procedures (APHA-AWWA-WPCF, 1995). The measurements of COD and the concentration of ILs were performed in a filtrate, after filtration of the sample. Degree of ILs removal and degree of COD removal were expressed in percent $(\%)$.

Determining the morphological parameters proceeded in the following way. Three vital unstained microscope preparations from each sample were prepared. Then, activated sludge was observed under microscope Nikon ECLIPSE Ni-U with the objective $4 \mathrm{x}$. During this observation approximately 40 images at $1280 \times 960$ pixels were taken. After collecting images, morphological parameters describing size (mean projected area, average perimeter, diameter) and shape of flocs (convexity and circularity) were estimated with the use of the NIS ELEMENTS AR software (Nikon). For this purpose special automated procedure was used. A description of all mentioned morphological parameters of activated sludge flocs has been presented elsewhere (Gendaszewska \& Liwarska-Bizukojć 2013).

\section{Results and discussion}

\section{Effect of ionic liquids on the activated sludge}

The effect of the tested ionic liquids on more important morphological parameters such as the mean projected area of the activated sludge floc is shown in Fig. 1. The values of this parameter in each case were generally lower in comparison with the value of this parameter for the control test. This indicates probably higher hydrophobicity of compounds with more than one substituent which results in the decrease in the flocs size. What is more, decrease of mean projected area was observed for compounds at the high initial concentrations equal to
$25 \mathrm{mg} \mathrm{l}^{-1}$ and $50 \mathrm{mg} \mathrm{l}^{-1}$. It is the most apparent for the test with IL 6, where the value of this parameter at these concentrations ranged from $7552 \pm 1245 \mu \mathrm{m}^{2}$ to $7918 \pm 278 \mu \mathrm{m}^{2}$, whereas the value of this parameter for the control was approximately $12486 \pm 1900 \mu^{2}$. Even at a low initial concentration $\left(1 \mathrm{mg} \mathrm{l}^{-1}\right)$ the smallest flocs were found for this chemical compound $\left(8901 \pm 1300 \mu \mathrm{m}^{2}\right)$ in comparison to other tested compounds. Quite large standard variations reflect differences in biological material from different series.

The values of circularity of activated sludge flocs were at similar level for all tested compounds (0.315-0.355). Also, the convexity of flocs varied slightly from $0.725-0.741$ in the tests with/without ionic liquids. The highest values of circularity were found for IL 4 and IL 6 at the initial concentration of $25 \mathrm{mg} \mathrm{l}^{-1}$ and were equal to 0.355 and 0.346 , respectively. Therefore, smaller and more circular flocs have been found for higher ionic liquids concentration in wastewater. The obtained results confirm that the ionic liquids with longer alkyl chain cause decrease in the surface area of activated sludge flocs. It can lead to deterioration of the sedimentation properties of activated sludge (Eikelboom \& van Buijsen 1999). As a consequence, the efficiency of wastewater treatment can also be deteriorated. The relationship between the biomass concentration (expressed as a VSS) and the concentration of the tested compounds is shown in Fig. 2.

What is interesting, the lower concentrations of biomass in comparison with the control test were obtained in almost all cases. This was particularly evident at concentrations of 5,25 and $50 \mathrm{mg} \mathrm{l}^{-1}$, for which the biomass concentrations were in the range from $0.628 \mathrm{~g} \mathrm{l}^{-1}$ to $0.709 \mathrm{~g} \mathrm{l}^{-1}$. For the control test biomass concentration was equal $0.773 \mathrm{~g} \mathrm{l}^{-1}$. Minimal impact of increasing concentration of ILs on the measured values of VSS was observed. It confirmed that the presence of tested ILs at higher concentrations slightly inhibits the growth of the activated sludge biomass. For the lowest initial concentration of ionic liquids $\left(1 \mathrm{mg} \mathrm{l}^{-1}\right)$, the concentration of biomass was the most similar to the values obtained for the control test and was: $0.8213 \mathrm{~g} \mathrm{l}^{-1} ; 0.7774 \mathrm{~g} \mathrm{l}^{-1} ; 0.7242 \mathrm{~g} \mathrm{l}^{-1}$ and $0.7228 \mathrm{~g} \mathrm{l}^{-1}$ respectively for consecutive ionic liquids.

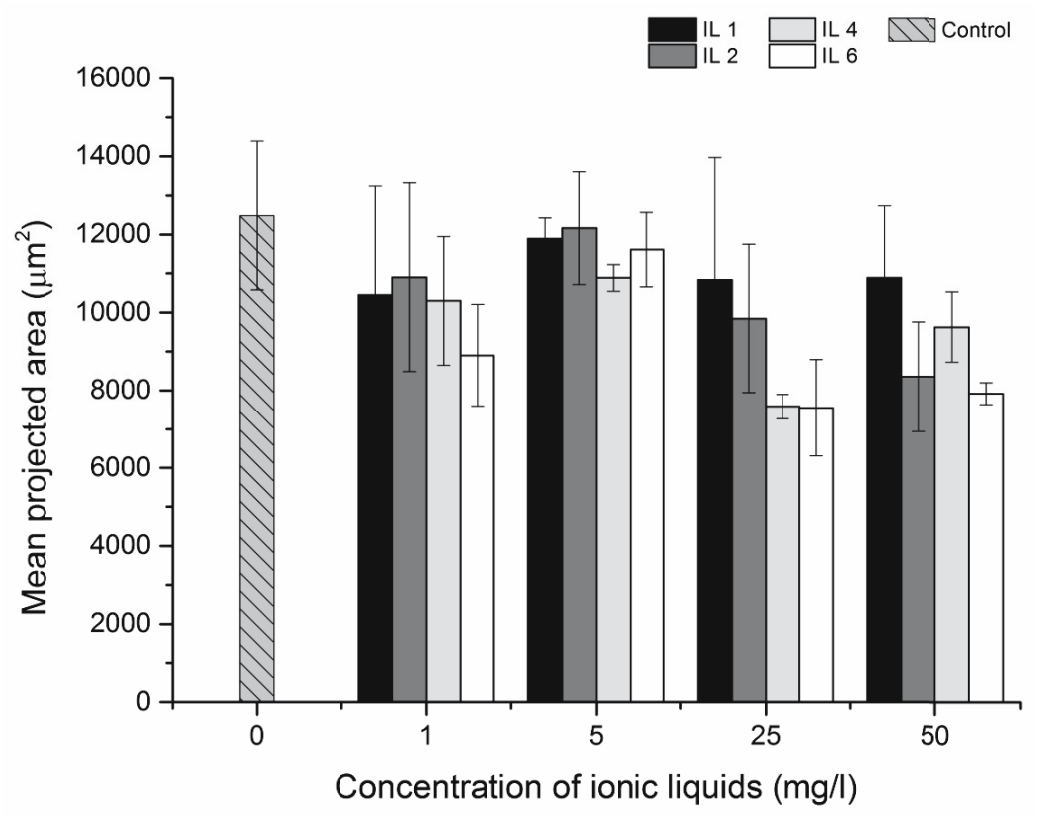

Fig. 1. Comparison of the mean projected area of activated sludge flocs exposed and not exposed to ILs 


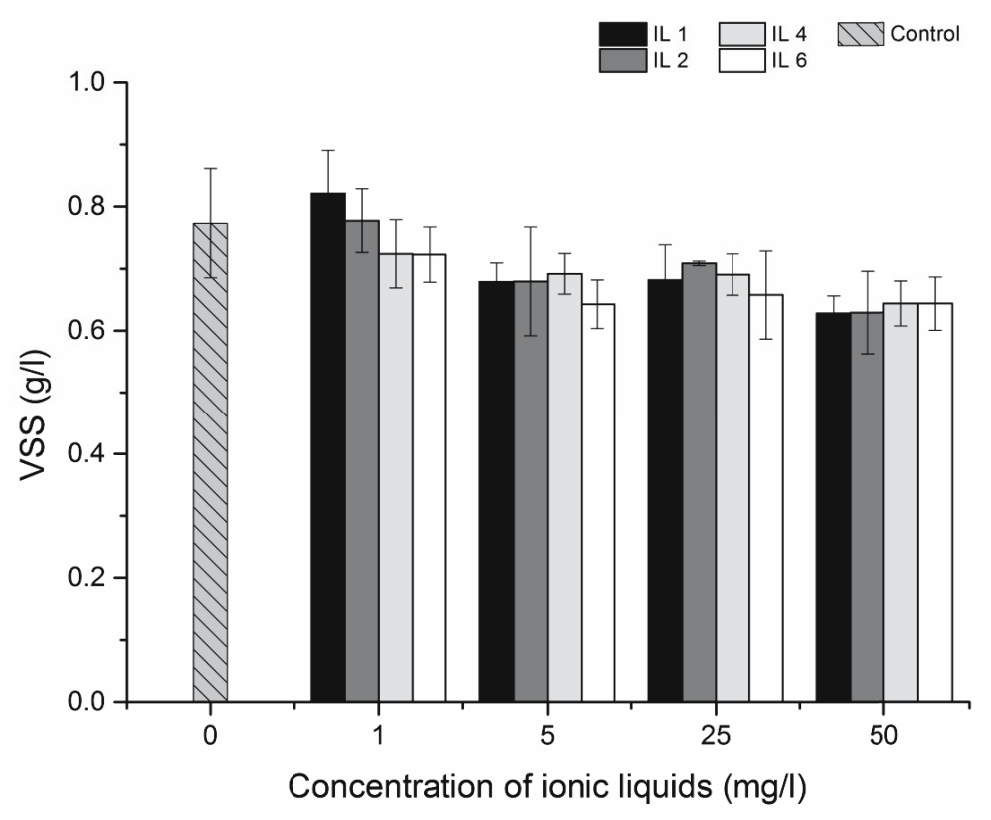

Fig. 2. Comparison of biomass concentration of activated sludge

\section{The effectiveness of organic compounds removal from wastewater}

The removal degree of organic pollutants was expressed as the loss of COD of wastewater in the liquid phase, as well as the loss of ILs in wastewater. It was found that the presence of ILs at the low concentration in wastewater ( 1 and $\left.5 \mathrm{mg} \mathrm{l}^{-1}\right)$ did not hinder the removal of other organic compounds during biological wastewater treatment (Fig. 3).

However, if the initial concentration of ILs in wastewater was high (25 $\mathrm{mg} \mathrm{l}^{-1}$ and $50 \mathrm{mg} \mathrm{l}^{-1}$ ), the degree of contamination removal from wastewater was deteriorated. The strongest effect was observed for IL 6 with the longest alkyl chain. The mean value of the degree of COD removal for this ionic liquid at the highest concentration of $50 \mathrm{mg} \mathrm{l}^{-1}$ was in the lowest level $(71.8 \%)$ in comparison with the test without ILs (94.2\%). The relationship between the degree of ILs removal from wastewater and the concentration of these compounds in wastewater is shown in Fig. 4. Also in this case, the influence of initial concentration and chemical structure of tested compounds on values of determined indicator was observed. The degree of ILs removal from wastewater generally decreased with the increase of ILs initial concentration in wastewater.

At the highest concentration of ionic liquids (50 $\mathrm{mg} \mathrm{l}^{-1}$ ), the degree of ILs removal was in the low range for all compounds (7.80-14.4\%). The value of ILs removal was the highest in the tests with IL 6 with the longest alkyl chain and was equaling $56.4 \%$ at concentrations $1 \mathrm{mg} \mathrm{l}^{-1}$. In comparison, at the same concentration other ILs were removed in the range from $20.2 \%$ to $33.3 \%$. Low values of ILs removal suggest that ionic liquids are not readily biodegradable, what was confirmed in several reports (Gathergood et al. 2005, Docherty et al. 2007).

All these observations lead to the conclusion that the degree of COD removal and ILs removal depend on the initial concentration of ILs in wastewater and the chemical structure of tested compounds.

\section{Sorption isotherm}

In order to describe the capacity of sludge for the adsorption of ILs, coefficient $\mathrm{K}_{\mathrm{D}}$ was determined for each of ionic liquids tested in the adsorption experiments. The obtained results from the test and the literature are collected in Table 3. For comparison the susceptibility of ionic liquids to sorption, compounds composite with imidazolium cation and halide anion were chosen. These results showed that the strength of adsorption process depends on adsorbent types. The lowest sorption coefficient was observed for ILs on clayey brown soil and was in the range from 2.6 to $4.2 \mathrm{~L} \mathrm{~kg}^{-1}$. However, the highest values of $K_{D}$ were found for aquatic sediments, such as marine sediments with $\mathrm{K}_{\mathrm{D}}$ of $400 \mathrm{~L} \mathrm{~kg}^{-1}$ for [BMIM][Cl] and $2450 \mathrm{~L} \mathrm{~kg}^{-1}$ for [HMIM] [Cl]. The values of this coefficient determined in this study do not differ significantly from the literature. It means that the inactivated sludge behaves as a typical adsorbent.

Higher values of $\mathrm{K}_{\mathrm{D}}$ for marine sediments may be a result of a higher content of clay, which increases the adsorption capacity of the adsorbent (Beaulieu et al. 2008). Also, the structure of ionic liquids plays an important role in sorption. It was found that the longer alkyl chain, the stronger binding of the adsorbate by the adsorbent. The highest values of sorption coefficient were observed for [HMIM][Cl] and for IL 6 with six carbon atoms in the alkyl chain, as well. It may be due to Van der Waals strong interactions between the adsorbent and solution of the tested compounds having more hydrophobic alkyl chains (Markiewicz et al. 2009). The influence of the adsorbent composition and lipophilicity of ionic liquids on the adsorption process was confirmed in many reports (Beaulieu et al. 2008, Studzińska et al. 2008). It should also be noted that no difference was found between $\mathrm{K}_{\mathrm{D}}$ for [BMIM][Cl] and $\mathrm{K}_{\mathrm{D}}$ for [BMMIM][Cl] with an additional methyl group in the molecule. Similar hydrophobicity of these compounds causes similar sorption capacity of ionic liquids having two or three substituents. The same order of magnitude of the $\mathrm{K}_{\mathrm{D}}$ values for IL 2 and IL 4 confirms this assumption. 


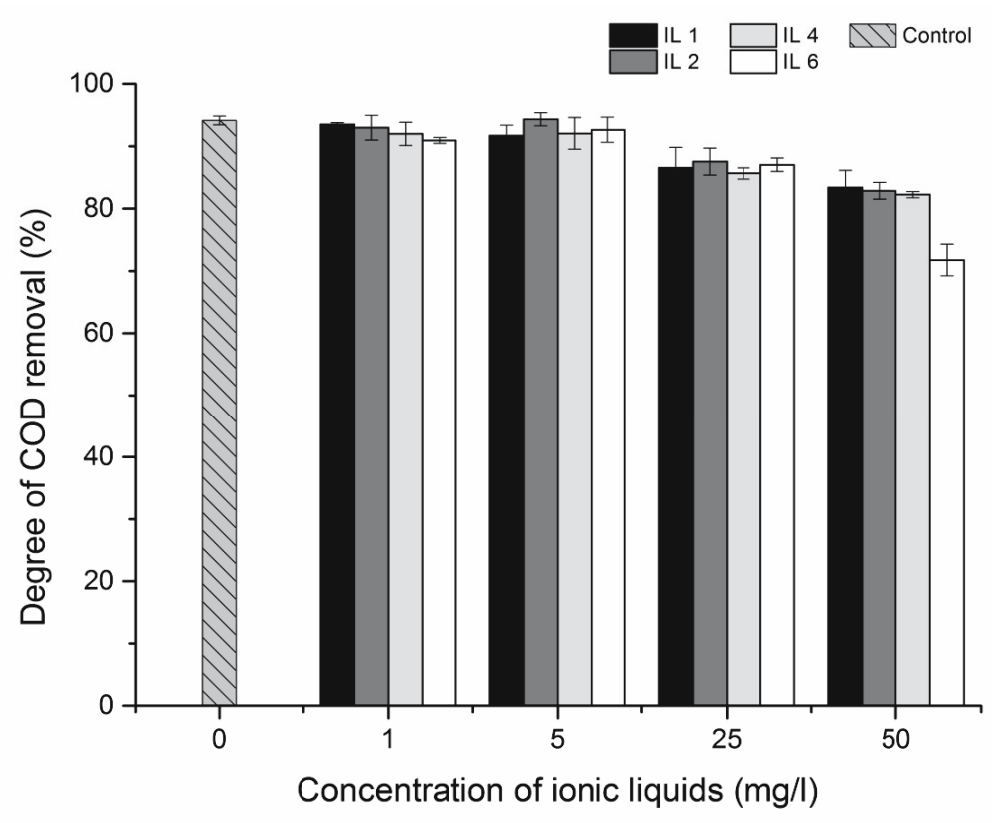

Fig. 3. Comparison of the degree of COD removal

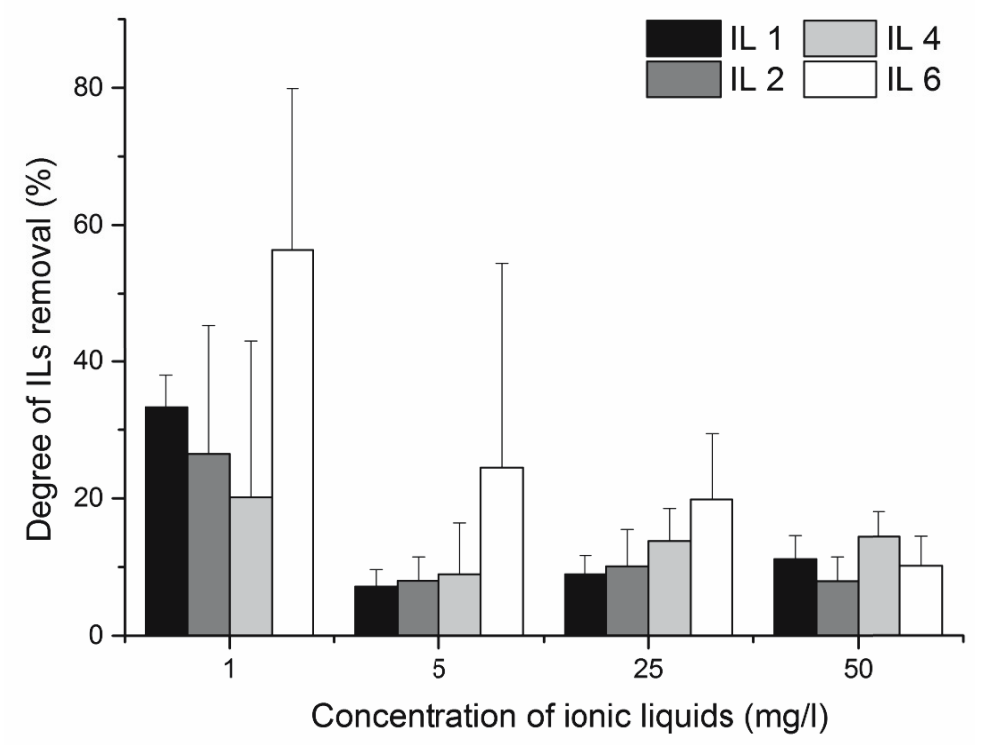

Fig. 4. Comparison of the degree of ILs removal

Freundlich isotherm was used to describe experimental data for the first three ionic liquids. Comparison of the literature data and the parameters for the tested compounds are listed in Table 4.

In order to compare experimental data of $\mathrm{K}_{\mathrm{f}}$ with literature data, the obtained values of $\mathrm{K}_{\mathrm{f}}$ are converted to the following unit: $\left.\left[(\mathrm{mol} \mathrm{kg})^{-1}\right)\left(\mathrm{mol} \mathrm{l}^{-1}\right)^{-1 / n}\right]$. The experimental results are in good correlation with literature data. The $\mathrm{n}$ factor of the Freundlich expression was slightly higher than one. However, values of correlation coefficient from 0.97 to 0.98 indicate that Freundlich isotherms well describe the sorption of tested compounds.

The intensity of adsorption, which is also expressed as a $\mathrm{K}_{\mathrm{f}}$ coefficient, generally increases with the increase of the alkyl chain length of the ionic liquids. Example of fitting
Freundlich isotherm for IL 1 is shown in Fig. 5. The adsorption isotherm determined for IL 6 has a different character than adsorption isotherms for other ionic liquids. Quite a good rate of correlation coefficient (0.95) indicates that experimental data for IL 6 correspond to the Langmuir isotherm (Fig. 6). Also high value of the $\mathrm{n}$ factor (2.13) in the Freundlich equation excludes Freundlich model.

Estimated Langmuir constants $\mathrm{K}_{\mathrm{L}}=0.13 \mathrm{~L} \mathrm{mg}^{-1}$ and $\mathrm{q}_{\mathrm{L}}=3.84 \mathrm{mg} \mathrm{g}^{-1}$ were calculated from the slopes of this line. Langmuir isotherm model satisfactorily described the adsorption of IL 6 on inactivated sludge due to the mechanism of adsorption isotherm. Molecules of this IL adsorb on surfaces so strongly that they do not move across the surface. With increasing concentrations of the liquid the saturation point is reached. Also longer alkyl chain with six carbon atoms and larger molecular 
Table 3. Comparison of $\mathrm{K}_{\mathrm{D}}$ coefficient for different adsorbents. Ionic liquids investigated were [EMIM][Cl]

(1-ethyl-3-methylimidazolium chloride), [BMIM][CI] (1-butyl-3-methylimidazolium chloride), [HMIM][CI] (1-hexyl-3-methyimidazolium chloride), [BMMIM][Cl] (1-butyl-2,3-dimethylimidazolium chloride) and tested ionic liquids (Tab. 1).

\begin{tabular}{|c|c|c|c|}
\hline Ionic liquid & $\mathrm{K}_{\mathrm{D}}\left[\mathrm{L} \mathrm{kg}^{-1}\right]$ & Type of sorbent & References \\
\hline [EMIM][Cl] & 2.6 & \multirow{3}{*}{ Clayey brown soil } & \multirow{3}{*}{ Mrozik et al. 2012} \\
\hline [BMIM][Cl] & 3.7 & & \\
\hline [HMIM][Cl] & 4.2 & & \\
\hline [BMIM][Cl] & 95 & \multirow{3}{*}{ Pond sediment } & \multirow{3}{*}{ Beaulieu et al. 2008} \\
\hline [BMMIM][Cl] & 110 & & \\
\hline [HMIM][Cl] & 110 & & \\
\hline IL 1 & $4-95$ & \multirow{4}{*}{ Inactivated sludge } & \multirow{4}{*}{ Author's own work } \\
\hline IL 2 & $97-183$ & & \\
\hline IL 4 & $51-226$ & & \\
\hline IL 6 & 93-305 & & \\
\hline [BMIM][CI] & 400 & \multirow{2}{*}{ Marine sediments } & \multirow{2}{*}{ Stępnowski 2005} \\
\hline [HMIM][Cl] & 2450 & & \\
\hline
\end{tabular}

Table 4. Comparison of Freundlich isotherm parameters for different adsorbents

\begin{tabular}{|c|c|c|c|c|c|}
\hline \multirow{2}{*}{ Ionic liquid } & \multicolumn{3}{|c|}{ Freundlich isotherm parameters } & \multirow{2}{*}{ Type of sorbent } & \multirow{2}{*}{ References } \\
\hline & $\begin{array}{c}\mathrm{K}_{\mathrm{f}} \\
\left(\mathrm{mol} \mathrm{kg}^{-1}\right)\left(\mathrm{mol} \mathrm{l}^{-1}\right)^{-1 / n}\end{array}$ & $\mathrm{n}$ & $\mathrm{R}^{2}$ & & \\
\hline IL 1 & 53.7 & 1.21 & 0.98 & \multirow{3}{*}{ Inactivated sludge } & \multirow{3}{*}{ Author's own work } \\
\hline IL 2 & 30.9 & 1.49 & 0.98 & & \\
\hline IL 4 & 14.5 & 1.56 & 0.97 & & \\
\hline [EMIM][Cl] & 16.7 & 1.33 & 0.99 & \multirow{3}{*}{ Clayey brown soil } & \multirow{3}{*}{ Mrozik et al. 2012} \\
\hline [BMIM][Cl] & 19.5 & 1.16 & 0.99 & & \\
\hline [HMIM][Cl] & 20.2 & 1.14 & 0.99 & & \\
\hline [BMIM][Cl] & 3.17 & 1.01 & 0.99 & \multirow{2}{*}{ Pond sediment } & \multirow{2}{*}{ Beaulieu et al. 2008} \\
\hline [HMIM][Cl] & 1.05 & 1.01 & 0.99 & & \\
\hline [EMIM][Cl] & 188.8 & 1.59 & 0.98 & \multirow{3}{*}{$\begin{array}{l}\text { Alluvial agricultural } \\
\text { soil }\end{array}$} & \multirow{3}{*}{ Mrozik et al. 2012} \\
\hline [BMIM][Cl] & 238.7 & 1.62 & 0.99 & & \\
\hline [HMIM][Cl] & 348.3 & 1.59 & 0.96 & & \\
\hline [BMIM][Cl] & 0.70 & 3.57 & 0.89 & \multirow{3}{*}{ Activated carbon } & \multirow{3}{*}{ Palomar et al. 2009} \\
\hline [HMIM][Cl] & 1.52 & 4.17 & 0.72 & & \\
\hline [OMIM][Cl] & 2.15 & 4.55 & 0.66 & & \\
\hline
\end{tabular}

mass cause better performance of adsorption. This was confirmed in previous studies (Liwarska-Bizukojć et al. 2013).

\section{Conclusions}

The influence of ionic liquids on the growth of biomass and morphological parameter of sludge flocs was observed. The presence of each of imidazolium ionic liquids in wastewater generally caused growth inhibition of biomass and flocs. Biomass concentration, degree of COD removal and ILs removal depend on the initial concentration of ILs in wastewater and the chemical structure of tested compounds, as well. What is more interesting, the highest level of removal was observed for IL 6 at the lowest initial concentration. Therefore, this imidazolium ionic liquid is easier to remove from wastewater but has the highest impact on activated sludge biomass.

The adsorption tests indicated that all ionic liquids can be adsorbed with a different strength on the inactivated sludge. Moreover, adsorption was higher for ionic liquid with the longest alkyl chain length (IL 6) than other ionic liquids. The adsorption process for IL 1, IL 2 and IL 4 is described by the Freundlich isotherm, while the adsorption of IL 6 is described by Langmuir isotherm.

In conclusion, the presence of ionic liquids tested in wastewater is not without the influence on the process of its treatment. In addition the obtained results have proven that adsorption on sludge represents one of removal mechanisms of ILs from wastewater. 


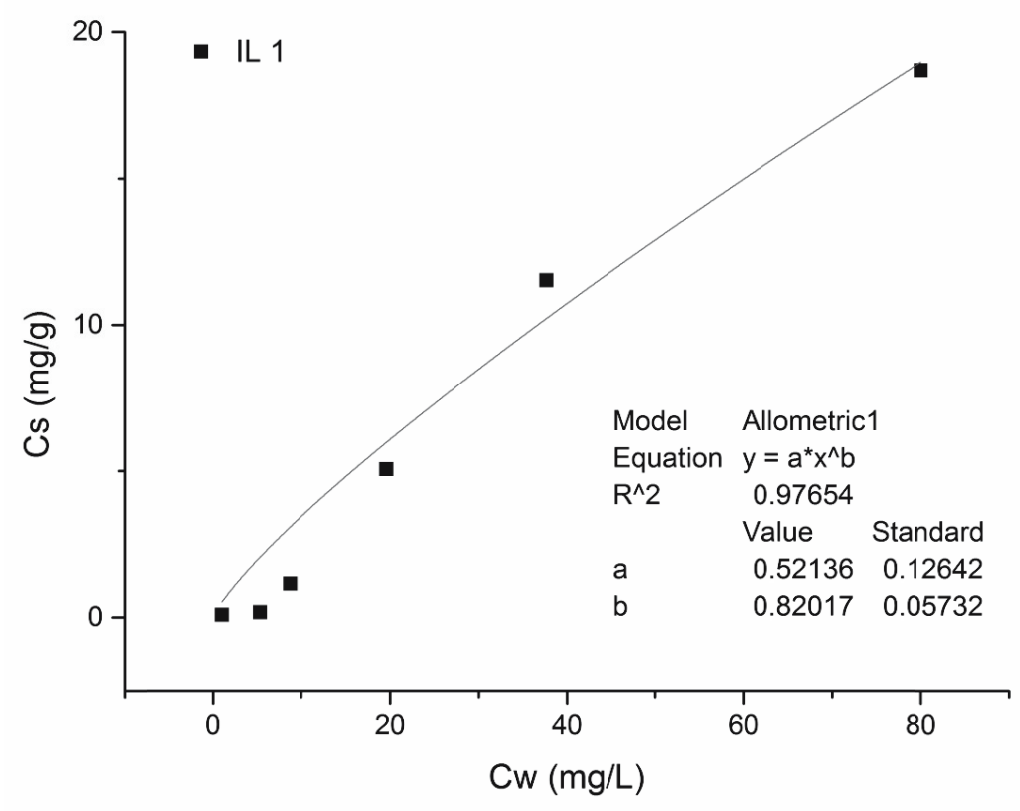

Fig. 5. Freundlich adsorption isotherm for IL 1

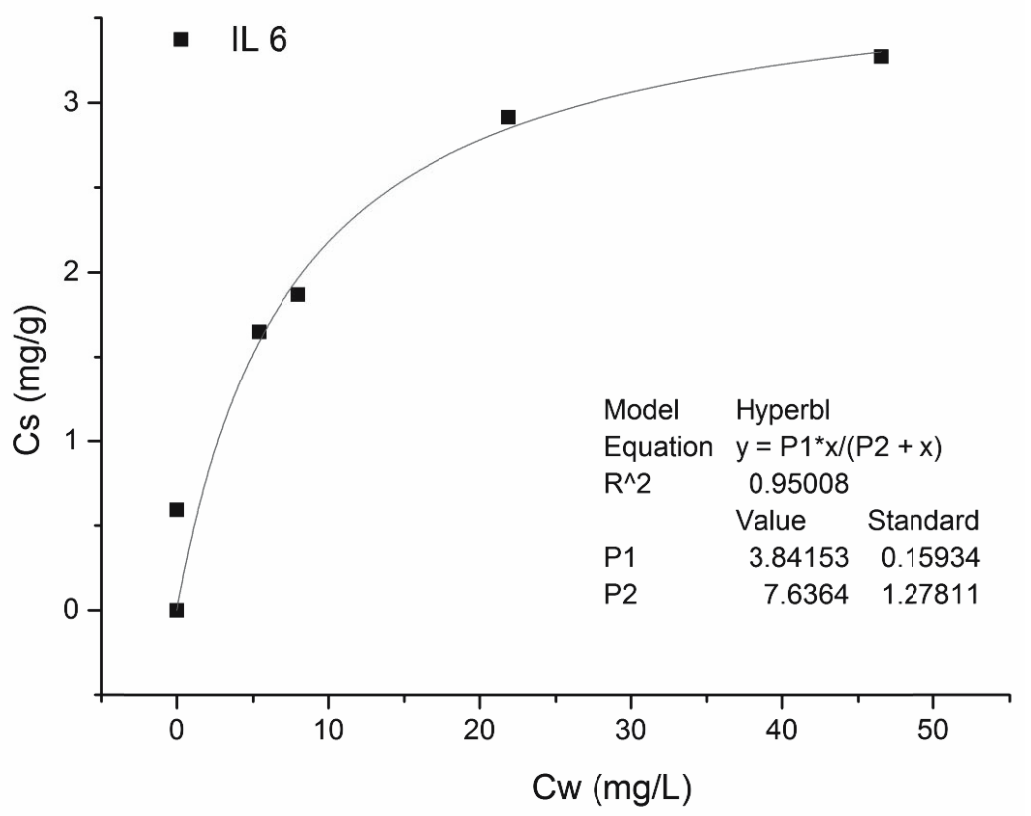

Fig. 6. Langmuir adsorption isotherm for IL 6

\section{References}

APHA-AWWA-WPCF. (1995). Standard methods for the examination of water and wastewater (19th ed.). Washington 1996.

Beaulieu, J.J., Tank, J.L. \& Kopacz, M. (2008). Sorption of imidazolium-based ionic liquids to aquatic sediments, Chemosphere, 70, pp. 1320-1328.

Docherty, K.M., Dixon, J.K. \& Kulpa, C.F. (2007). Biodegradability of imidazolium and pyridinium ionic liquids by an activated sludge microbial community, Biodegradation, 18, pp. $481-493$.

Eikelboom, D.H. \& van Buijsen, H.J.J. (1999). Handbook for microbiological investigation of sludge, Seidel-Przywecki Sp. z o.o., Szczecin 1999. (in Polish)
Giles, C.H., Smith, D. \& Huitson, A. (1974). A general treatment and classification of the solute adsorption isotherm. I. Teoretical, Journal of Colloid and Interface Science, 47, pp. 766.

Gathergood, N., Scammells, P.J. \& Garcia, M.T. (2005). Biodegradable ionic liquids. Part II. Effect of the anion and toxicology, Green Chemistry, 7, pp. 9-14.

Gendaszewska, D. \& Liwarska-Bizukojć, E. (2013). Comparison of imidazolium ionic liquids and traditional organic solvents: effect on activated sludge process, Water Science and Technology, 68, 12, pp. 2654-2660.

Gorman-Lewis, D.J. \& Fein, J.B. (2004). Experimental study of the adsorption of an ionic liquid onto bacterial and mineral surfaces, Environmental Science and Technology, 38, pp. 2491-2495. 
Liwarska-Bizukojć, E., Maton, C., Stevens, Ch.V. \& Gendaszewska, D. (2013). Biodegradability and kinetics of the removal of new peralkylated imidazolium ionic liquids, Journal of Chemical Technology and Biotechnology, 89, 5, pp.763-768.

Liwarska-Bizukojć, E. (2008). Adsorption of selected anionic and nonionic surfactants on the activated sludge, Przemyst Chemiczny, 87, 5, pp. 506-508. (in Polish)

Luis, P., Ortiz, I., Aldaco, R. \& Irabien, A. (2007). A novel group contribution method in the development of a QSAR for predicting the toxicity (Vibrio fischeri EC50) of ionic liquids, Ecotoxicology and Environmental Safety, 67, pp. 423-429.

Markiewicz, M., Jungnickel, C., Markowska, A., Szczepaniak, U., Paszkiewicz, M. \& Hupka, J. (2009). 1-Methyl3-octylimidazolium chloride - sorption and primary biodegradation analysis in activated sewage sludge, Molecules, 14, pp. 4396-4405.
Mrozik, W., Kotłowska, A., Kamysz, W. \& Stepnowski, W. (2012). Sorption of ionic liquids onto soils: Experimental and chemometric studies. Chemosphere, 88, pp. 1202-1207.

Paderewski, M. (1999). Adsorption processes in chemical engineering, Wydawnictwo Naukowo Techniczne, Warszawa 1999. (in Polish)

Palomar, J., Lemus, J., Gilarranz, M.A. \& Rodriguez, J.J. (2009). Adsorption of ionic liquids from aqueous effluents by activated carbon, Carbon, 47, 7, pp. 1846-1856.

Polish Standard (PN): Water and wastewater PN 72/C-04550. (in Polish)

Stępnowski, P. (2005). Preliminary assessment of the sorption of some alkyl imidazolium cations as used in ionic liquids to soils and sediments, Australian Journal of Chemistry, 58, pp. 170-173.

Studzińska, S., Sprynskyy, M. \& Buszewski, B. (2008). Study of sorption kinetics of some ionic liquids on different soil types, Chemosphere, 71, pp. 2121-2128.

\section{Wpływ nowo syntetyzowanych imidazoliowych cieczy jonowych na pracę osadu czynnego}

Streszczenie: Celem badań było określenie wpływu czterech imidazoliowych cieczy jonowych (CJ) na proces oczyszczania ścieków metodą osadu czynnego. Ustalono, że obecność tych związków w ściekach wpływa negatywnie na przyrost biomasy oraz powoduje zmniejszanie wielkości kłaczków osadu czynnego. Najsilniejszy efekt zaobserwowano dla jodku 1-heksylo-2H-3-metylo-4,5-dimetyloimidazoliowego (CJ 6), posiadającego najdłuższy łańcuch alkilowy. Poza tym odnotowano zależność, że stopień usunięcia CJ wzrasta wraz z wydłużaniem się łańcucha alkilowego w podstawniku kationu oraz maleje wraz ze wzrostem początkowego stężenia cieczy jonowych w ściekach. Pomimo tego, że najwyższy stopień usunięcia CJ ze ścieków zaobserwowano dla CJ 6, to obecność tej cieczy jonowej w ściekach hamowała wzrost biomasy jak i wzrost kłaczków w największym stopniu. Dodatkowo przeprowadzono badania mające na celu zanalizowanie zdolności osadu jako sorbentu do usunięcia CJ ze ścieków. W toku prowadzonych badań wykazano, że nowo syntetyzowane ciecze jonowe mogą być adsorbowane na inaktywowanym osadzie czynnym. Ciecz jonowa CJ 6 uległa adsorpcji w wyższym stopniu niż pozostałe testowane związki. Adsorpcja ta została opisana izotermą Langmuira, natomiast adsorpcja pozostałych cieczy jonowych opisana została za pomocą izotermy Freundlicha. 